\title{
Comparison of Traps Collecting Propolis by Honey Bees
}

\section{Antonios E. Tsagkarakis ${ }^{1 *}$, Tatiani Katsikogianni' ${ }^{2}$, Konstantinos Gardikis ${ }^{2}$, Ioannis Katsenios ${ }^{2}$, Eleni Spanidi2 ${ }^{2}$ Georgios N. Balotis ${ }^{3}$}

${ }^{1}$ Laboratory of Agricultural Zoology and Entomology, Agricultural University of Athens, Athens, Greece

${ }^{2}$ APIVITA S.A., Markopoulo Mesogaias, Greece

${ }^{3}$ Institute of Agronomical Sciences, Hellenic Ministry of Rural Development and Food, Kifissia, Greece

Email: *atsagarakis@aua.gr

How to cite this paper: Tsagkarakis, A.E., Katsikogianni, T., Gardikis, K., Katsenios, I., Spanidi, E. and Balotis, G.N. (2017) Comparison of Traps Collecting Propolis by Honey Bees. Advances in Entomology, 5, 68-74.

https://doi.org/10.4236/ae.2017.52006

Received: March 11, 2017

Accepted: March 28, 2017

Published: March 31, 2017

Copyright $\odot 2017$ by authors and Scientific Research Publishing Inc. This work is licensed under the Creative Commons Attribution International License (CC BY 4.0).

http://creativecommons.org/licenses/by/4.0/

\begin{abstract}
The last few years numerous publications have been published about the properties and plant origin of propolis, the glue-like resinous product collected by honeybees. Although, only one scientific experiment has been previously conducted on propolis collection techniques by honey bees, making the relative literature extremely limited in this area. The present study scopes to evaluate the effect of the trap types on the quantity of propolis collected by honeybees. For this reason, at two different locations, five different types of propolis collection traps, applied on Langstroth bee hives, were tested: 3 hand-cut screens plus one commercial screen on the top bars, as well as a lateral side modification of a Langstroth hive. Results show that two hand-cut screens with smaller openings $(1 \times 1 \mathrm{~mm}$ and $2 \times 2 \mathrm{~mm})$ as well as the commercial screen collected significantly more propolis than the others $\left(\mathrm{F}_{4,41}=\right.$ 43.21, $\mathrm{P}<0.0001)$. Furthermore, the two hand-cut screens filled faster with propolis.
\end{abstract}

\section{Keywords}

Propolis Collection, Honeybee, Langstroth Hive

\section{Introduction}

The word "propolis" is compound, derived from the Greek words $\pi \rho o$ (pro = before) and $\pi$ ólıৎ (polis = city), which means the last defense point before the city (or the hive). The use of propolis dates back at least to $300 \mathrm{BC}$ [1], when its resinous and glue-like properties were made use of. Greeks have used propolis for abscesses; Hippocrates recommended propolis on wound's healing while Democritus suggested that longevity and health could be accomplished by the 
consumption of bee products among which, propolis. Assyrians have used it for healing wounds and tumors while Egyptians had included propolis in the mummification ingredients [2].

Propolis is made from raw-materials collected by honeybees from living plants after mixing with wax and it is used for construction of their hives, to seal hive walls and strengthen comb cells [3] [4] [5]. Bud resins mixed with bee salivary enzymes [6] and beeswax have been used in the hive not only as a building material, but also as antimicrobial agent against a wide variety of pathogens (bacteria, fungi, protozoa)and pests (mites) [7] [8] [9]. Worker bees bring these pathogens into the hive and are common in the honeybees' natural environment [10]. Owing to its antimicrobial properties, propolis can reduce disease at the colony level and provide social immunity to the bee family [11]. Propolis antimicrobial activity has been attributed to flavonoid aglycones and phenolic and hydroxycinnamic acids. The content in bud resins of different plant species varies widely [12]. Propolis has 500 times more flavonoids than orange fruit. It consists of more than 200 ingredients, which make it "veritable cascade of aromatic nutrient" remarkable to fight all type of pathogens [13]. In one recent analysis of propolis, 150 compounds were identified in only one sample [14]. Although, it appears that with every new analysis applied, new compounds are found.

The composition of propolis varies and depends on the surrounding plants. Differences in color, odor and chemical compounds are observed depending on the source and the season of gathering [15]. Moreover, some colonies seem to show more avid behavior on propolis collection.

A large variety of trees and shrubs is used by bees to collect propolis resins. Each region and colony seems to have its own preferred resin sources, which results in large variation of final composition. In Europe, honeybees preferably collect resins from leaf buds of Populus species [16].

The average production of propolis per colony per year has been described as 10 to $300 \mathrm{~g}$ but the production depends on the bees, the forest resources, the climate and the trapping mechanism [17] [18].

Most of the methodology used to collect propolis, comes from practical knowledge and techniques used by bee-keepers, but because of the wide range of variation those techniques are not comparable. The most commonly used collection methods employ special traps placed on top of a hive, below the covers or next to lateral walls inside the hives so that bees do not mix wax with the propolis and no contamination occurs during harvesting [16] [19] [20] [21]. Traps are screens with small holes which simulate cracks in the hive walls. Bees try to seal the holes and fill the trap with propolis. The most economic trap design is an inner cover with a large hole, covered with regular nylon fly screen, secured in place by the points of nails and a perforated frame [16] [19] [20] [21].

A factor to be evaluated is the presence of light and air circulation in the stimulation of propolis collection. Slightly opened covers over the traps are used as a methodology for this reason. 
Propolis is removed from traps by cooling the plastic sheets or fly-screens for a few hours in a refrigerator or freezer. Once cooled, the propolis becomes brittle and can be removed from the screens by simply flexing and brushing them, preferable in a cold environment as the heat makes it sticky again. The trap is then ready for re-use [16]. Although, only one scientific experiment has been previously conducted on propolis collection techniques by honey bees [22]. Results of this study indicated that a Langstroth hive with the lateral side modified in order to receive an aluminum plate produced the highest amount of propolis. Although, the lack of other studies on that field, makes the relative literature extremely limited.

Objective of the present study is to evaluate the effect of the trap types on the quantity of propolis collected by honeybees.

\section{Materials and Methods}

\subsection{Location and Duration of Study}

The study was conducted in two different locations for 2 years, from 2013 to 2014. The first location was the Institute of Agricultural Sciences (I.A.S.) in the Syggros Estate, at Amaroussion, Athens, Greece ( $38^{\circ} 03^{\prime} 42.0^{\prime \prime} \mathrm{N}, 23^{\circ} 48^{\prime} 41.2^{\prime \prime} \mathrm{E}, 270$ $\mathrm{m}$ elevation)and the second was the apiary of the Apivita S. A. facility, in Markopoulo Mesogaias, Attika, Greece $\left(37^{\circ} 52^{\prime} 02.1^{\prime \prime N}, 23^{\circ} 54^{\prime} 44.4^{\prime \prime} \mathrm{E}, 200 \mathrm{~m}\right.$ elevation). The two locations were in about $30 \mathrm{~km}$ distance from each other. Monthly average temperature and relative humidity for I.A.S. area was $24.6^{\circ} \mathrm{C} / 47.6 \%$, $26.9^{\circ} \mathrm{C} / 44.8 \%, 26.3^{\circ} \mathrm{C} / 46.1 \%, 22.1^{\circ} \mathrm{C} / 55.7 \%$ and for Markopoulo Mesogaias $25.2^{\circ} \mathrm{C} / 52.8 \%, 28.0^{\circ} \mathrm{C} / 47.0 \%, 27.8^{\circ} \mathrm{C} / 47.1 \%, 24.2^{\circ} \mathrm{C} / 53.4 \%$ for June, July, August and September, respectively.

\subsection{Characteristics and Setting of Hives}

Thirty Langstroth hives colonized by Apismellifera Macedonica with 1-year queens were placed in circular settlement with $3 \mathrm{~m}$. distance from each other. Each hive was placed on a metal stand of $25 \mathrm{~cm}$ in height. Colonies were equal in adult and brood population (9 and 4 frames, respectively).

\subsection{Experimental Plan}

Five different propolis collection traps were tested on the quantity of propolis they collect. The tested traps were 4 different screens placed on the top bars and a hive modification, as follows:

1) Commercial plastic screens with rectangle openings $(3 \times 16 \mathrm{~mm})$ (Figure $1(\mathrm{a})$ ).

2) Polypropylene hand-cut plastic screens with $4 \times 4 \mathrm{~mm}$ square openings (Figure 1(b)).

3) Polypropylene hand-cut plastic screens with $2 \times 2 \mathrm{~mm}$ square openings (Figure 1(c)).

4) Polypropylene hand-cut plastic screens with $1 \times 1 \mathrm{~mm}$ square openings (Figure 1(d)). 


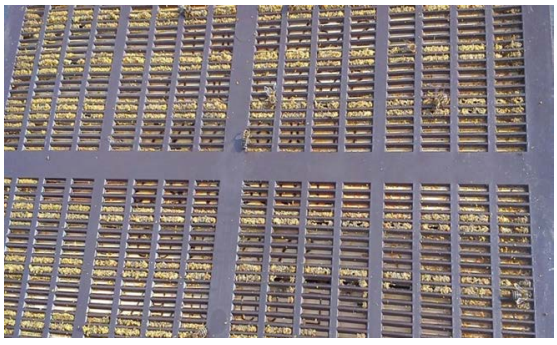

(a)

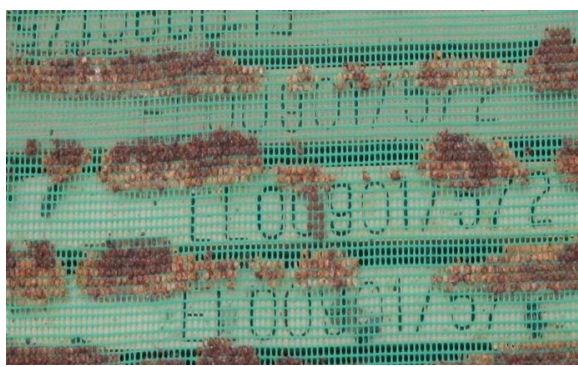

(c)

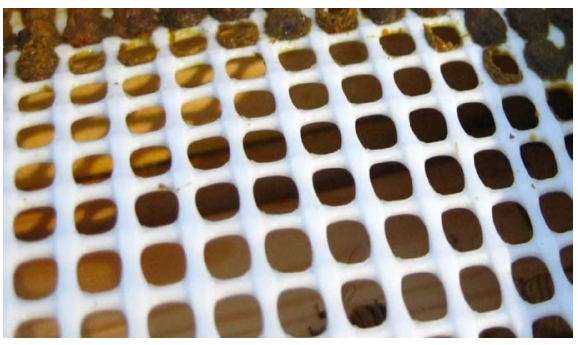

(b)

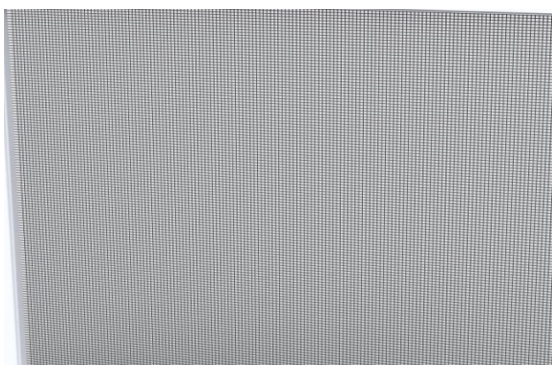

(d)

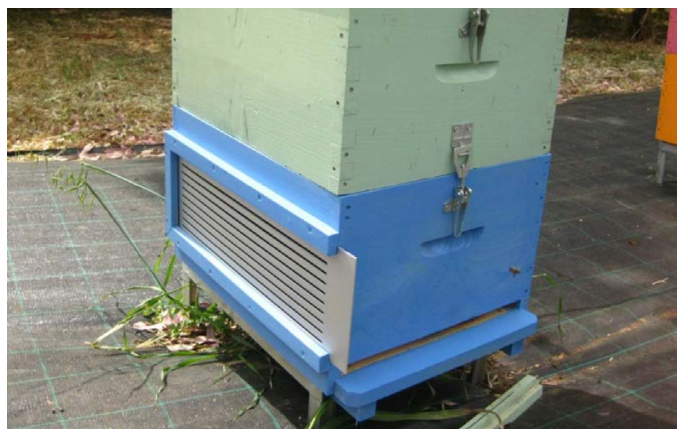

(e)

Figure 1. Traps for propolis collection used in the present experiment: (a) commercial screen; (b) $4 \times 4 \mathrm{~mm}$ screen; (c) $2 \times 2 \mathrm{~mm}$ screen; (d) $1 \times 1 \mathrm{~mm}$ screen; (e) lateral side hive modification.

\section{5) Modified Langstroth hive body (Figure 1(e)).}

The hand-cut screens were attached with small pins in a wooden frame, $2 \mathrm{~cm}$ in height, which also acted as apostate from the top cover. The commercial screen was attached as commercially suggested. The modified Langstroth hive was constructed with a $15 \times 55 \mathrm{~cm}$ aluminum plate inserted in the lateral side of Langstroth hive body, according to Abu Fares et al. (2008). Rectangular slots ( $45 \times$ $0.4 \mathrm{~cm}$ ) were made in the plate with $1 \mathrm{~cm}$ spaces between them (Figure 1(e)).

Five replications per treatment were used under the Completely Randomized Design. Hives were inspected twice per week. Whenever the first screen was filled with propolis, all the screens were removed and transported to the laboratory of the I.A.S.. Screens were placed in plastic bags and freezed $\left(-18^{\circ} \mathrm{C}\right)$ for 24 $h$. Then, propolis removed by simply flexing the screens above a clean paper sheet on the laboratory bench and weighed. Four repetitions were performed with different screen assignment per repetition: in June 2013, September 2013, July 2014 and September 2014. 


\subsection{Data Analysis}

Data were subjected to log-transformation and then to one-way analysis of variance, or t-test. Differences between treatment means were tested for significance with Tukey's HSD test $(\mathrm{P}=0.05)$. All analyses were conducted using JMP (Version 13; SAS Institute, Cary, NC).

\section{Results}

Statistical analysis showed significant differences in the collected propolis between the different screens $\left(\mathrm{F}_{4,41}=43.21, \mathrm{P}<0.0001\right)$.

Screens with $1 \mathrm{x} 1 \mathrm{~mm}$ openings collected the most propolis $(29.57 \pm 7.59 \mathrm{gr})$, followed by those with $2 \times 2$ openings $(23.70 \pm 5.63 \mathrm{gr})$ and the commercial screens $(15.62 \pm 4.05 \mathrm{gr})$, without any significant differences between them) (Figure 2). In the $4 \mathrm{x} 4 \mathrm{~mm}$ screens significantly less propolis was collected (1.15 \pm $0.90 \mathrm{gr}$ ) compared with the other screens, while in the lateral modified hives no propolis was collected. It has to be mentioned that bees were noticed to put propolis in the screens in order to seal the spaces between the wooden frames.

Mean collection time for all the aforementioned quantities was $20.5 \pm 0.5$ days. In two of the repetitions the $2 \times 2 \mathrm{~mm}$ screens were filled faster and signed the removal of all the screens and, so, the beginning of the first measurement. In the other two, the $1 \times 1 \mathrm{~mm}$ screens were filled faster.

No significant differences observed between the areas $(t=0.53, P=0.602)$ and the dates $\left(\mathrm{F}_{3,41}=2.26, \mathrm{P}=0.110\right)$.

\section{Discussion}

The present study indicated the differences in the quantity of the collected propolis between the different screens, or hive modifications. The plastic screens over the top bars were found to collect more propolis compared to hive modifications. Between the screens with the square opening, the $1 \times 1 \mathrm{~mm}$ were the most preferable, followed by the $2 \times 2 \mathrm{~mm}$, while the $4 \times 4 \mathrm{~mm}$ were the less preferable and collected significantly less propolis. Also, the first two were filled

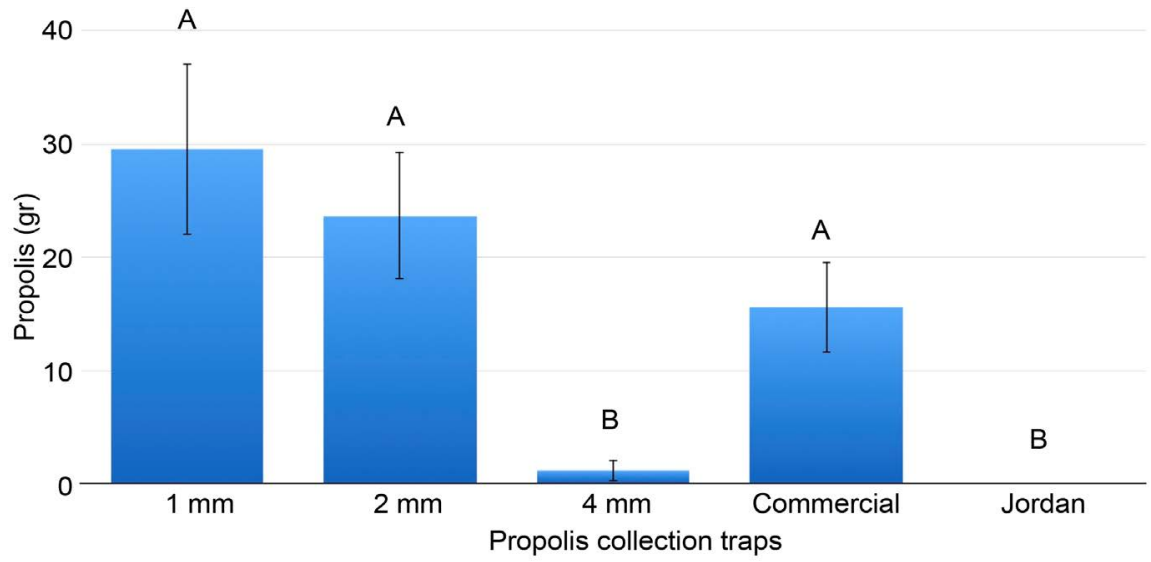

Figure 2. Quantity of propolis (mean \pm S.E.) collected in traps from honeybees during the experiment (columns without common letter have significant difference). 
faster with propolis compared with all the other treatments. The lateral hive modification did not collect any propolis during the first two repetitions of the experimental procedure. Results do not agree with Abu Fares et al. [22], who found that the lateral-side modification collected more propolis than the plastic top screen and the back-side modification. A possible explanation of this could be the different environmental conditions between Jordan and Greece. This explanation agrees with Lebedev [23], who refers that honeybees prefer to fill with propolis firstly the upper part of the hive, where the main temperature loss is happening. Generally, temperature loss is a great stimulus for bees to collect and store propolis. This is supported by the difference in the quantity of the collected propolis (15.77 gr. per hive the yearly maximum for Jordan [22], compared with 29.57 gr. for Greece, in only three months of experimentation in our study), if we take in account the lower average temperature in Greece comparing with Jordan.

Results of the present study indicate that screens with smaller openings are collecting more propolis in shorter time. Screens with $1 \times 1 \mathrm{~mm}$ and $2 \times 2 \mathrm{~mm}$ openings collected more propolis than those with $4 \times 4$ openings. Furthermore, the first two aforementioned screens were filled with propolis faster than all the others. Our results agree with Lebedev [23] who refers that honeybees are much more active in filling smaller cracks than bigger. This may be due to the ease of filling the smaller cracks than compared with the bigger.

Propolis collection from honeybees in the current study appears to be attributable primarily to use over the top bar screens, with the exception of these of large opening dimensions $(4 \times 4 \mathrm{~mm})$. In the lateral side hive modification, no propolis was collected. Although no significant differences were found between the two hand-cut screens with small openings and the commercial screen, the first two collected more propolis in a shorter period. These results suggest a way in which the beekeepers can construct their own propolis collection screens with a much lower budget (reduced about $90 \%$ : about $0.20 €$ vs 3 - $7 €$ per screen), which can collect more propolis in a shorter period of time. Further studies are needed to elucidate the effect of other factors in propolis collection, as the race of the bees and other techniques.

\section{Acknowledgements}

The authors would like to thank Mr. Sotirios Strigkos for the technical support in beehive keeping.

\section{References}

[1] Haydak, M.H. (1954) Propolis. Report of the Iowa State Apiarist for 1953, 74-87.

[2] Kuropatnicki, A.K., Szliszka, E. and Krol, W. (2013) Historical Aspects of Propolis Research in Modern Times. Evidence-Based Complementary and Alternative Medicine, 2013, Article ID: 964149. https://doi.org/10.1155/2013/964149

[3] Bankova, V.S., Castro, D.S.L. and Marcucci, M.C. (2000) Propolis: Recent Advances in Chemistry and Plant Origin. Apidologie, 31, 3-15.

https://doi.org/10.1051/apido:2000102 
[4] Hegazi, A.G. (1998) Propolis an Overview. J. Bee Informed, 5, 22-23.

[5] Pereira, A.S., Norsell, M., Cardoso, J.N., Neto, F.R.A. and Ramos, M.F.S. (2000) Rapid Screening of Polar Compounds in Brazilian Propolis by High-Emperature High-Resolution Gas Chromatography-Mass Spectrometry. Journal of Agricultural and Food Chemistry, 48, 5226-5230. https://doi.org/10.1021/jf000594p

[6] Kaczmarek, F. and Dębowski, W.J. (1983) Content of $\alpha$ - and $\beta$-Amylase in Propolis. Acta Poloniae Pharmaceutica, 40, 121.

[7] Simone-Finstrom, M. andSpivak, M. (2010) Propolis and Bee Health: The Natural History and Significance of Resin Use by Honey Bees. Apidologie, 41, 295-311. https://doi.org/10.1051/apido/2010016

[8] Evans, J.D. and Schwarz, R.S. (2011) Bees Brought to Their Knees: Microbes Effective Honey Bee Health. Trends in Microbiology, 19, 614-620.

[9] Shimanuki, H. and Knox, D.A. (2000) Diagnosis of Honey Bee Diseases. Agriculture Handbook No. AH690. United States Department of Agriculture, Beltsville.

[10] Chechetkina, U.E., Evteeva, N.I. andRechkin, A.I. (2010) Comparison of the Composition of Enterobacteria in Honey Bees Apismellifera L. during the Wintering and in the Active Honey Season. Herald Nizhegor University N, 2, 475-478.

[11] Evans, J.D. and Spivak, M. (2010) Socialized Medicine: Individual and Communal Disease Barriers in Honey Bees. Journal of Invertebrate Pathology, 103, 62-72.

[12] Bankova, V., Popova, M. and Trusheva, B. (2006) Plant Sources of Propolis: An Update from a Chemist's Point of View. Natural Product Communications, 1, 1023 1028.

[13] Botushanov, P.I., Grigorov, G.I. and Aleksandrov, G.A. (2001) A Clinical Study of a Silicate Toothpaste with Extract from Propolis. Folia Medica, 43, 28-30.

[14] Greenaway, W., May, J., Scaysbrook, T. and Whatley, F.R. (1990) Identification by Gas Chromatography-Mass Spectrometry of 150 Compounds in Propolis. Zeitschriftfür Naturforschung, 46, 111-121.

[15] Souza, E.A., Zaluski, R., Veiga, N. and Orsi, R.O. (2016) Effects of Seasonal Variations and Collection Methods on the Mineral Composition of Propolis from Apismellifera linnaeus Beehives. Brazilian Journal of Biology, 76, 396-401. https://doi.org/10.1590/1519-6984.16714

[16] Krell, R. (1996) Value-Added Products from Beekeeping. FAO Agricultural Services Bulletin, 124, Food and Agriculture Organization of the United Nations, Rome, Italy.

[17] Ochi, T. (1981) A New Method to Collect Propolis. Honeybee Science, 2, 16.

[18] Andrich, G., Fiorentini, R. and Consiglieri, A. (1987) Characteristics of Some Samples of Propolis from the Ligurian Coast. Cittadelle Api, 28, 30-31, 34, 35, 37, 38.

[19] Crane, E. (1990) Beekeeping: Science, Practice and World Recourses. Heinemann, London.

[20] Iannuzzi, J. (1993) Propolis Collectors. American Bee Journal, 133, 104-107.

[21] Clay, H. (2002) Propolis Collection: A Value-Added Potential. Hive Lights, 14.

[22] Abu Fares, R.J., Nazer, I.K., Darwish, R.M. and Abu Zarqa, M. (2008) Honey Bee Hive Modification for Propolis Collection. Jordan Journal of Agricultural Sciences, 4, 138-147.

[23] Lebedev, V.I. (1979) About Uniting of Honey Bee Colonies in Autumn. Pchelovodstvo, 9, 10-11. (In Russian) 
Submit or recommend next manuscript to SCIRP and we will provide best service for you:

Accepting pre-submission inquiries through Email, Facebook, LinkedIn, Twitter, etc. A wide selection of journals (inclusive of 9 subjects, more than 200 journals)

Providing 24-hour high-quality service

User-friendly online submission system

Fair and swift peer-review system

Efficient typesetting and proofreading procedure

Display of the result of downloads and visits, as well as the number of cited articles Maximum dissemination of your research work

Submit your manuscript at: http://papersubmission.scirp.org/

Or contact ae@scirp.org 